\title{
Effect of Consumer Awareness of Education Material, Source of Information, and Value of Materialism on Behavior as A Smart Adolescent Consumer
}

\author{
Mia Fitriyah Setianingrum* \\ Department of Family and Consumer Sciences, \\ Faculty of Human Ecology, \\ Bogor Agricultural University \\ *Corresponding author: miafitriyah@gmail.com \\ Lilik Noor Yuliati \\ Department of Family and Consumer \\ Sciences, Faculty of Human Ecology, \\ Bogor Agricultural University
}

\begin{abstract}
This study aims to analyze the effect of consumer awareness about education material, source of information, and value of materialism toward behavior as smart consumer on junior high school student in urban and rural areas of Bogor. Samples in this study are $9^{\text {th }}$ grade junior high school students as much as 125 students that consisting of 62 students in urban and 63 students in rural areas. The sampling technique is cluster random sampling with the consideration that students have obtained consumer education materials on social sciences and Indonesian language for grade 7 to grade 9. Data were collected by selfadministered technique using questionnaires. The results showed that there are differences in consumer awareness about education material, source of information, and objective knowledge of students in urban and rural areas. Gender and source of information affect the behavior as smart consumer on junior high school students.
\end{abstract}

Keywords: consumer awareness, education material ,materialism value, objective knowledge, smart consumer, source of information

\begin{abstract}
Abstrak. Penelitian ini bertujuan untuk mengetahui pengaruh kesadaran materi pendidikan konsumen, sumber informasi, dan nilai materialisme terhadap perilaku sebagai konsumen cerdas pada siswa Sekolah Menengah Pertama (SMP) di perkotaan dan perdesaan Bogor. Contoh dalam penelitian ini adalah siswa SMP kelas 9 sebanyak 125 siswa yang terdiri atas 62 siswa di perkotaan dan 63 siswa di perdesaan. Teknik pengambilan sampel secara cluster random sampling dengan pertimbangan bahwa siswa telah memperoleh materi pendidikan konsumen pada mata pelajaran Ilmu Pengetahuan Sosial (IPS) dan Bahasa Indonesia untuk kelas 7 hingga kelas 9. Pengambilan data dilakukan dengan teknik self-administered menggunakan alat bantu kuesioner. Hasil penelitian menunjukkan terdapat perbedaan kesadaran materi pendidikan konsumen, sumber informasi, dan pengetahuan objektif siswa di perkotaan dan perdesaan. Jenis kelamin dan sumber informasi berpengaruh terhadap perilaku sebagai konsumen cerdas pada siswa SMP.
\end{abstract}

Kata kunci: kesadaran konsumen, materi pendidikan, nilai materialisme, pengetahuan objektif, konsumen cerdas, sumber informasi 


\section{Introduction}

Geographical locations can be classified into urban and rural areas. Most urban areas are dominated by government and private institutions with adequate infrastructure of information and communication. While, in rural areas, information and communications infrastructure tends to be inadequate, as well as the level of education and economic community that is difficult enough and cause difficulty in obtaining the necessary information (Ratnasari 2008). Indonesia is a country with the fourth largest consumer of the world where its consumers are currently in an increasingly complex market and more information with an increasingly diverse selection of products and services (Trade Ministry 2015). This is feared can make consumers more vulnerable to fraud. In addition, the main problem of consumers in Indonesia today is the low awareness of rights and responsibilities (Simanjuntak 2014). The era of globalization has triggered and influenced human consumption behavior to globalization of life attitude and cultural that called consumerism (Wening 2012). The results of the Trade Ministry of Indonesia Republic mapping (Trade Ministry 2015) showed that the Indonesian Consumer Empowerment Index (IKK) in 2015 is still low, which is 34.17 from the maximum value of 100 while the IKK in 29 European countries, in 2011 has reached 51.31.

Adolescents are one of the most potent market segments because they are consumers who easily affected by the flood of products on the market. Based on the data of Junior Schooling Statistic 2015/2016, the number of junior high school students in Indonesia is 10040277 students. The number of junior high school students in West Java reached 1790762 students, the most student if it compared to the junior high school population in other provinces. Teenagers have high consumption behavior because they often use the allowance given to buy something that is not needed (Wulandari et al 2016). Government through the Directorate of Consumer Empowerment, the Ministry of Commerce has made various efforts to form smart consumers through various programs either directly or indirectly. In the field of education, the government integrates consumer education materials into subjects at the primary to secondary level. The National Consumer Protection Agency (NCPA 2012) states that the integration of consumer protection learning materials is available in subjects at elementary, junior and senior high schools, in social studies (SSS), Indonesian Language, and Economics at the General and Senior High School/Vocational High School level. Consumer education as one of means to form skills, attitudes, knowledge and understanding with the aim to develop awareness of consumer rights and responsibilities (Knights 2000).

Consumer education is not only obtained from schools. Teens, especially junior high school students can also obtain consumer education through other sources of information that is currently easy to accessible by anyone. One source of consumer education information is mass media. In the information age, mass media has become a part of society's life that can not be separated. Children and adolescents generally spend time each day watching television, listening to the radio, reading newspapers, or accessing various sites on the internet (Anwas 2011). Targeted marketing and communication media for children as consumers becomes the topic of discussion in order to improve the consumer protection of children (Sramova 2015). The value of materialism that exists in a person also 
influences it in behaving. Materialistic consumers tend to be young and pay great attention to their looks, purchases that tend to be unplanned (compulsive), and buy more than needed (Joung 2013). Various symptoms that lead to a materialistic lifestyle can be seen how modern shopping centers, such as supermarkets and malls, are filled with young students or students who exhibit consumptive behavior (Johan and Cahyo 2016). Being stuck in materialistic behavior is a threat because all the values of human life can be eroded, such as the value of faith, honesty, order, self-control, sacrifice, responsibility, and togetherness (Wening 2012). Based on the exposure, this study aims to: 1) Analyze the content of consumer education materials on social studies subjects (SSS) and Indonesian Language at Junior High School Students, 2) Identify differences in student characteristics, awareness of consumer education materials, information, materialism value, and behavior as smart consumer in junior high school students in urban and rural areas, 3) to analyze factors thst influencing behavior as smart consumer in junior high school students.

\section{Method}

This research use cross sectional study design with two approaches, that is qualitative and quantitative. The selection of research sites was conducted purposively based on the consideration that 20 Public Junior High School Bogor and 2 Public Junior High School Dramaga using Education Unit Level Curriculum (ULC) and teaching materials from Electronic School Book (ESB) that published by Book Center of Ministry of National Education. Withdrawal of sample research using probability sampling technique, that is cluster random sampling. An example in this study was a 9th grader from four randomly selected classes from both selected schools. A total of 62 students in urban and 63 students in rural areas became an sample in this study.

The data of research are primary data collected directly by self administered technique using questioner tool. During the completion of the kuasioner, researchers provide guidance so that students more easily understand the given problem. Consumer education material awareness variable and objective knowledge were measured using the instrument developed by researchers from the analysis of content of consumer education materials contained in Social Science textbooks (IPS) and Indonesian for grade 7, 8, and 9 grades with Cronbach's alpha value of 0.643 And 0.520 . The information source variables were measured using an instrument developed by the researcher based on the characteristics of intelligent consumers by the Ministry of Trade of the Republic of Indonesia (2013) received by students from various sources of information with Cronbach's alpha value of 0881. Variable values of consumer materialism were measured using Material Values Scale (VMS) developed by Richins and Dawson (1992) with Cronbach's alpha value of 0.741. Behavioral measurement variable as a smart consumer is measured using instruments developed based on the definition of intelligent consumers by the Ministry of Trade of the Republic of Indonesia and consumer empowerment instruments by Simanjuntak and Yuliati (2015) with Cronbach's alpha value of 0.724. Data were analyzed descriptively and inferensia. Descriptive analysis of the minimum value, maximum value, average, and standard deviation, while inference analysis in the form of t-test, correlation test, and multiple linear regression test. 


\section{Result}

\section{Characteristic of Student}

Based on the sex category, the number of girl students is higher with the percentage of 57.6 percent compared to the boys with the percentage of 42.4 percent. Almost all students in urban areas (95.2\%) and rural (98.4\%) are in the early adolescence category of 12 to 15 years (Monks et al 2001). This is because students are at the same level of education, the 9th grade of Junior High School (JHS). Most students (urban 77.4\% and rural 92.1\%) earn an allowance of 10000 to 20000 IDR per day. The average pocket money of students in urban 18758 IDR per day, not much different from the average pocket money of students in rural areas, which amounted to 17412 IDR per day. Overall, there were no significant differences between the characteristics of students in urban and rural areas.

\section{Awareness of Consumer Education Material}

Awareness of consumer education materials is divided into two dimensions, namely awareness of educational materials about consumer rights and awareness of educational materials about consumer lialibility.

Table 1 Mapping of educational materials on consumer rights and lialibilities on social studies subjects and Indonesian Language at 7, 8, and 9 grade

\begin{tabular}{|c|c|c|c|c|c|c|c|}
\hline \multirow[t]{2}{*}{ No } & \multirow[t]{2}{*}{ Consumer education materials } & \multicolumn{3}{|c|}{ Social Sciences } & \multicolumn{3}{|c|}{$\begin{array}{l}\text { Indonesian } \\
\text { Language }\end{array}$} \\
\hline & & 7 & 8 & 9 & 7 & 8 & 9 \\
\hline & Consumer Right & & & & & & \\
\hline 1. & $\begin{array}{l}\text { Right to comfort, safety, and safety } \\
\text { of consumption }\end{array}$ & & & & & $\sqrt{ }$ & \\
\hline 2. & Right to choose goods / services & $\sqrt{ }$ & & & & & \\
\hline 3. & $\begin{array}{l}\text { Right to right, clear and honest } \\
\text { information }\end{array}$ & $\sqrt{ }$ & & & $\sqrt{ }$ & & \\
\hline 4. & Rights at hearings and complaints & & & & & $\sqrt{ }$ & $\sqrt{ }$ \\
\hline 5. & $\begin{array}{l}\text { Rights of advocacy, protection, } \\
\text { and dispute resolution }\end{array}$ & & & & & & \\
\hline 6. & Right of coaching and education & & & & & $\sqrt{ }$ & \\
\hline 7. & $\begin{array}{l}\text { Rights are served truthfully and } \\
\text { honestly }\end{array}$ & $\sqrt{ }$ & & & & & \\
\hline \multirow[t]{2}{*}{8.} & Right to get compensation & & & & & $\sqrt{ }$ & \\
\hline & Consumer liability & & & & & & \\
\hline 1. & $\begin{array}{l}\text { Read / follow procedures for the } \\
\text { use of goods / services }\end{array}$ & & & & & $\sqrt{ }$ & \\
\hline 2. & $\begin{array}{l}\text { Good faith in buying goods / } \\
\text { services transactions }\end{array}$ & $\sqrt{ }$ & $\sqrt{ }$ & & & & \\
\hline 3. & Pay according to exchange rate & $\sqrt{ }$ & & & & & \\
\hline 4. & $\begin{array}{l}\text { Following the legal dispute over } \\
\text { consumer protection disputes }\end{array}$ & $\sqrt{ }$ & & & & & \\
\hline
\end{tabular}

Educational materials on consumer rights and lialibility are in Social Science subjects (grades 7 and 8) and Indonesian Language (grades 7, 8, and 9). 
Consumer education materials on Social Sciences subjects are inserted into discussions on economic principles, economic action, household arrangements, consumer principles in addressing needs, how to set up the family income and expenditure budget, consumptive behavior, and resource scarcity and how to overcome scarcity of resources. In addition, consumer education materials contained in Indonesian subjects are inserted in the discussion of waste management, reading tables, composing language instructions, consumerism behavior, recognizing additives to food, paying attention to expiry time, and writing letters to readers

Based on the results of content analysis mapping that has been done in Table 1, only the right of consumer number 5, namely "Right to get advocacy, protection, and efforts to settle the dispute of consumer protection properly" which is not contained in textbooks. Educational materials on consumer rights number 2, namely "The right to choose goods and / or services and obtain goods and / or services in accordance with the exchange rate and conditions and promised guarantee" is mostly found in Social Science textbooks. Meanwhile, little educational material about consumer liability is found in both subjects. Overall, educational materials about rights and lialibilities found in textbooks are not explicitly explained and the numbers are limited. Consumer education materials in social science subjects are generally inserted in the chapter "Economic Principles", whereas in Indonesian subjects only inserted in text readings, such as news texts and discourse.

\section{Awareness of Education Material on Consumer Rights}

The results of research on the dimensions of awareness of educational materials about consumer rights, indicating that students have not remembered or know of any educational materials about consumer rights, especially material relating to the rights of number 1 and number 6 . This is allegedly because the educational material on consumer rights number 1 and number 6 is very limited, which is only found on the subjects of Bahasa Indonesia for grade 8. In addition, the material is only inserted in the text so that the reader is difficult to realize. Based on Table 2, the majority of students have awareness of educational materials about low-categorized consumer rights, at 66.1 percent in urban areas and 82.5 percent in rural areas. Only 3.2 percent of urban students and 1.6 percent of students in rural areas have high consciousness. This shows that students' awareness of educational materials about consumer rights is still low with the average index of students in urban areas (55.51) higher than in rural students (48.54). The low awareness of students is suspected because educational materials about consumer rights are not explicitly explained so that many students are unaware that they have obtained consumer education materials. The result of t-test shows that there is a significant difference between the awareness of educational materials about consumer rights in students in urban and rural $(p=0.016)$.

\section{Awareness of Educational Material on Consumer Liability}

The results of research on the dimensions of awareness of educational materials about consumer lialibilities, indicating that students have not remembered or know of any educational materials about consumer liability number 2 and number 4 . The results of the content analysis show that lialibilities 
2 and 4 are not explicitly explained and the numbers are limited. The lack of exposure to educational materials about consumer liability resulted in low awareness of students on the given material. Distribution of students based on awareness of educational materials about consumer liabilities shows 45.2 percent of students in urban areas and 71.4 percent of students in rural low category. Referring to Table 2, the average student index in urban is 64.52 and in rural area is 49.21. That is, students in urban areas have a moderate awareness while students in rural areas have low categorized awareness. This shows that students in urban areas have a better awareness of educational materials about consumer liability than students in rural areas. The findings are evidenced by the results of tTest that shows there is a significant difference between the awareness of educational materials about consumer liability in students in urban and rural ( $\mathrm{p}=$ $0.001)$.

Table 2 Distribution of students based on awareness of educational materials on consumer rights and lialibilities as well as territories

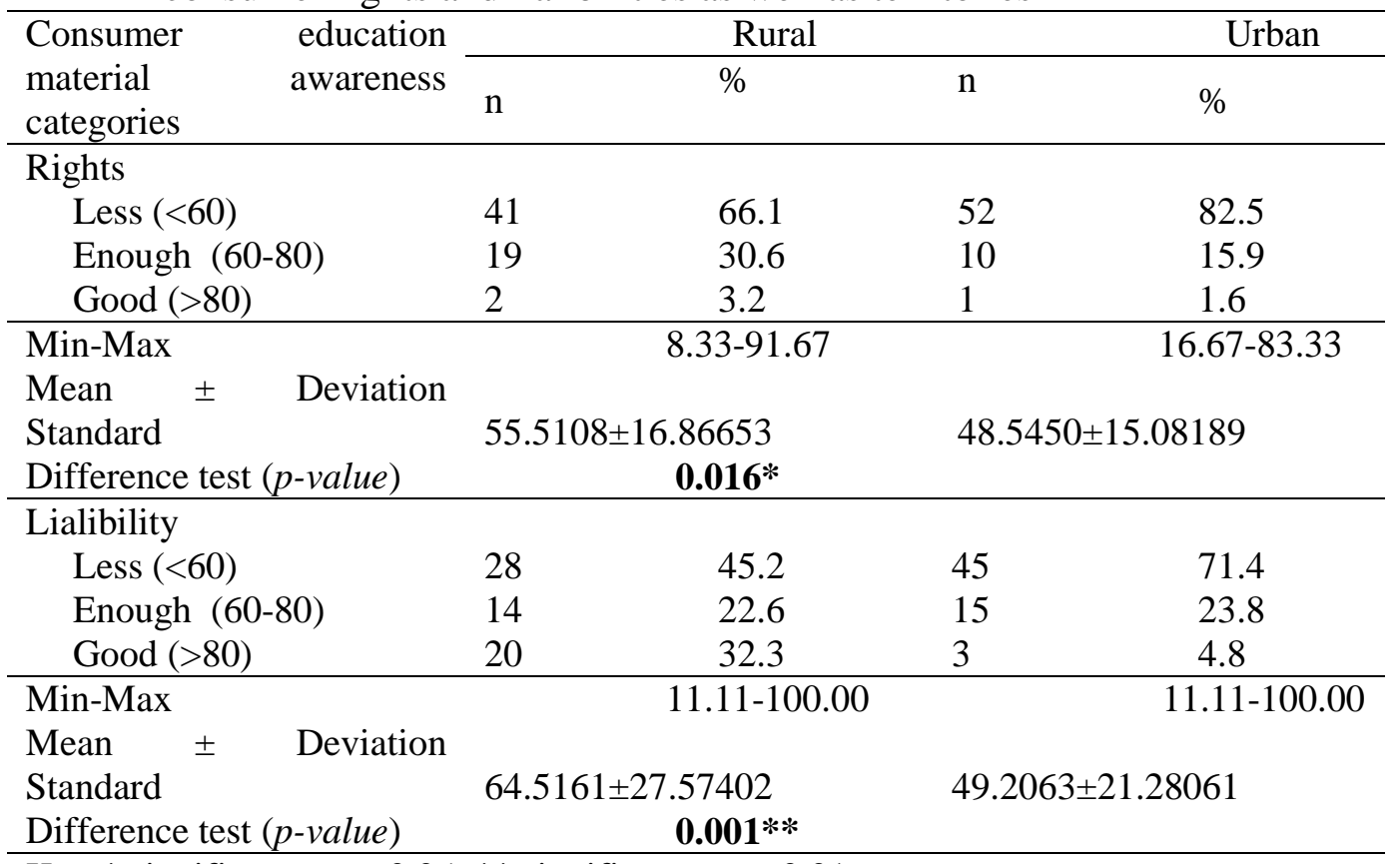

Ket: * significant at $\mathrm{p}<0.05 ; * *$ significant at $\mathrm{p}<0.01$

\section{Information Resources}

Referring to Table 3, the most informed source of "Consumer rights and duties" is the teacher. In the meantime, most sources provide information on "Research before buying", "Buy as needed", "Read product labels", "Ensure electronic products equipped with Indonesian warranty card", and "Prefer the needs rather than wishes" are parents. In addition, the sources that provide the most information on "Ensuring SNI-labeled products", "Manufacturers are required to include product expiry periods", and "Call for loving products made in Indonesia" are television. In general, the highest percentage of sources providing information about the smart consumer traits in urban and rural areas was parents (53.3\%), television (36.4\%), teachers $(31.6 \%)$, and internet $(27.5 \%)$. This shows that parents are the main source of information for students in urban and rural areas in obtaining consumer education. Radio is the least source of information 
about smart consumer traits (5.3\%). This is expected because of the lack of radio use in adolescents, especially junior high school students.

Table 3 Percentage of students who obtained information on consumer characteristics of intelligent consumers based on information sources

\begin{tabular}{|c|c|c|c|c|c|c|c|c|}
\hline \multirow{2}{*}{$\begin{array}{l}\text { Intelligent } \\
\text { information }\end{array}$} & \multicolumn{8}{|c|}{ Information Resources } \\
\hline & 1 & 2 & 3 & 4 & 5 & 6 & 7 & 8 \\
\hline Consumer rights and lialibility & 25.6 & 20.8 & 0.8 & 10.4 & 15.2 & 27.2 & 23.2 & 32 \\
\hline Thorough before buying & 26.4 & 43.2 & 4.8 & 17.6 & 14.4 & 12.8 & 79.2 & 30.4 \\
\hline Buy as needed & 15.2 & 14.4 & 1.6 & 1.6 & 1.6 & 7.2 & 89.6 & 39.2 \\
\hline $\begin{array}{l}\text { Ensure the product is marked with } \\
\text { Indonesian National Standard }\end{array}$ & 29.6 & 56 & 4.8 & 12.8 & 5.6 & 8 & 28 & 14.4 \\
\hline Read product labels & 24 & 33.6 & 1.6 & 12 & 13.6 & 11.2 & 49.6 & 22.4 \\
\hline $\begin{array}{l}\text { Ensure the electronic product comes } \\
\text { with an Indonesian warranty card }\end{array}$ & 21.6 & 12.8 & 2.4 & 3.2 & 14.4 & 2.4 & 26.4 & 5.6 \\
\hline $\begin{array}{l}\text { Manufacturers are required to } \\
\text { include a product's expiration period }\end{array}$ & 36.8 & 54.4 & 6.4 & 23.2 & 16.8 & 12.8 & 48 & 32 \\
\hline $\begin{array}{l}\text { Appeal to love products made in } \\
\text { Indonesia }\end{array}$ & 50.4 & 84 & 24 & 35.2 & 19.2 & 39.2 & 38.4 & 56.8 \\
\hline Putting needs first rather than desire & 17.6 & 8.8 & 1.6 & 7.2 & 2.4 & 9.6 & 88 & 52 \\
\hline Mean percentage & 27.5 & 36.4 & 5.3 & 13.7 & 11.5 & 21.7 & 52.3 & $\overline{31.6}$ \\
\hline
\end{tabular}

\section{Objective Knowledge}

\section{Objective Knowledge of Consumer Rights}

The results of the research on the objective knowledge dimension of consumer rights show that the majority of students in urban and rural areas do not understand the material related to consumer rights number 2 , that is, only one-fifth students understand the statement "Choose to use the executive train for safer and more comfortable reasons Although ticket prices are higher ". In addition, students in urban and rural areas lack understanding of the material related to consumer rights number 7 , ie only half of students who understand the statement "Consumers should not easily believe in promotional programs, sometimes some stores act dishonestly by raising the price of goods first and then At a discount ". This is allegedly because educational materials on consumer rights number 2 and 7 are only inserted in the chapter "Economic Principles" and are only found in Social Science textbooks for grade 7. The lack of exposure to information pertaining to the rights of number 7 makes it difficult for students to understand . Table 4 shows as many as 48.4 percent of students in urban areas and 33.3 percent of rural students have achievable objective knowledge of consumer rights in sufficient categories. That is, almost half of the students in urban and one third of students in rural areas quite understand the consumer rights listed in Consumer Protection Law Number 8 Year 1999. The average index of objective knowledge about consumer rights obtained by students in urban areas (68.55) is higher than the scores obtained by students in rural areas (62.04). This shows that the understanding of student's consumer rights in urban areas is better than rural students although their knowledge is sufficiently categorized. Students in urban 
areas are better at understanding statements relating to consumer rights than students in rural areas. This finding is evidenced by the results of t-test that shows there is a significant difference between objective knowledge about consumer rights in students in urban and rural $(\mathrm{p}=0.027)$.

Table 4 Distribution of students based on objective knowledge of rights and lialibilities

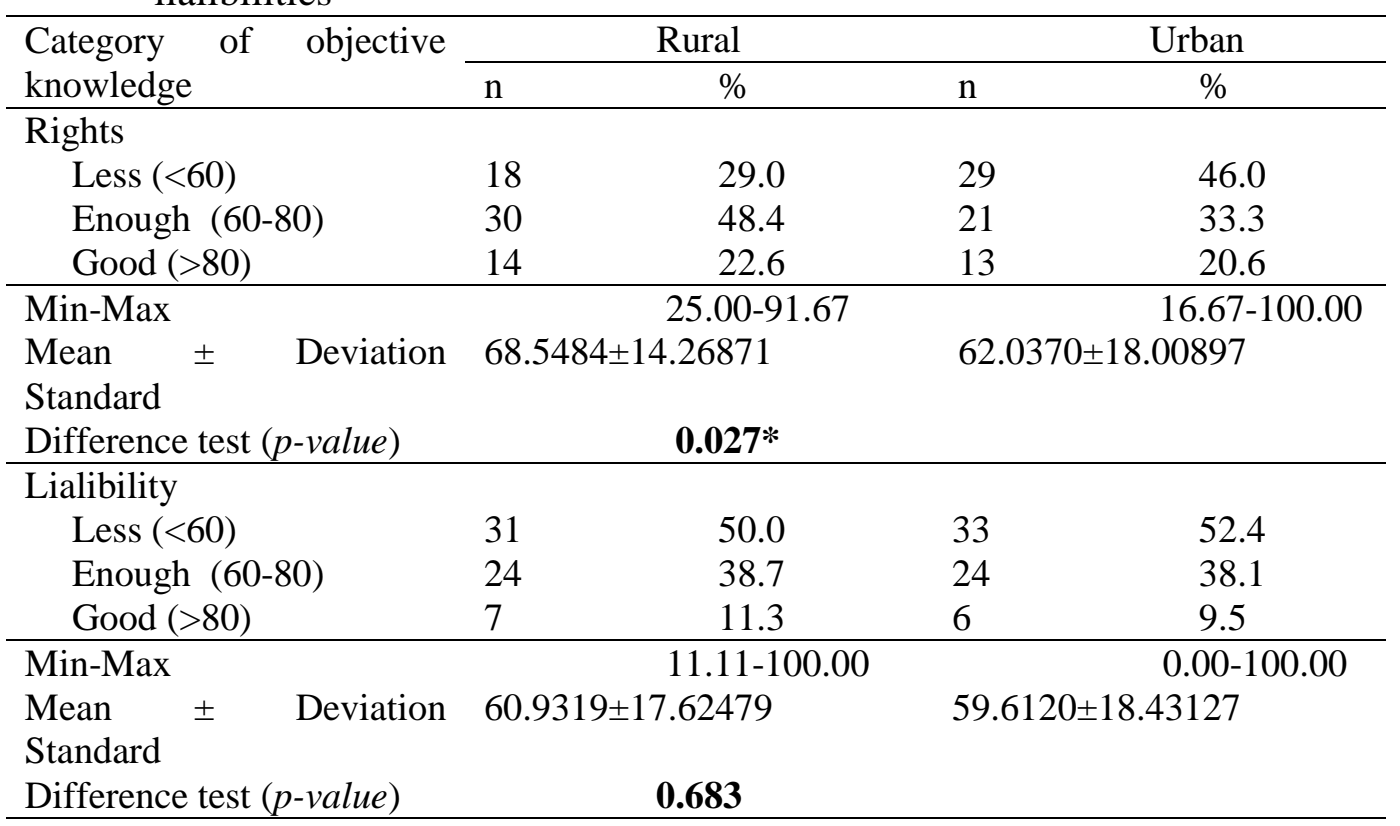

Decription: * significant at $\mathrm{p}<0.05$

\section{Objective Knowledge of Consumer Liability}

The results of the research on the objective knowledge dimension of consumer liabilities show that most students in urban and rural areas lack understanding of the material relating to consumer liability number 2, ie only 29.0 percent of students in urban and 36.5 percent of rural students who understand the statement " So much so that with the economic principle is expected every consumer can choose and utilize goods and services obtained as possible ". In addition, students in urban and rural areas are less aware of material relating to consumer liability number 4 , which is only 40.3 percent of urban students and 28.6 percent of rural students who understand the statement "One of the economic actions in meeting needs is to have a sense of responsibility". This is presumably because educational materials about consumer liabilities number 2 and 4 are only inserted in the chapter "Economic Principles" and are only found in Social Science textbooks for $7^{\text {th }}$ grade. The results of content analysis indicate that discussion of consumer education materials related to the lialibilities Numbers 2 and 4, are not explicitly explained so that students find it difficult to understand. Table 4 shows that half of the students in urban areas (50.0\%) and rural (52.4\%) have objective knowledge achievements about less-categorized consumer liabilities. The average index of objective knowledge about consumer liability obtained by students in urban areas (60.93) did not differ greatly from the scores of students in rural areas (59.61). This shows that both students in urban and rural students tend to be less aware of consumer liabilities. The result of t-Test did not 
show any significant difference between the achievement of objective knowledge about the students' consumer obligation in urban and rural $(\mathrm{p}=0.683)$.

\section{Materialism Value}

Richins and Dawson (1992) divide the value of materialism into three dimensions: success, centrality, and happiness. The value of materialism in the dimension of success is the student's judgment of one's success from the material or possessions he possesses; The value of materialism in the dimension of centrality is the student who makes the possession of matter as the ultimate goal of life; And the value of materialism in the dimension of happiness is the perception of students that the possession of matter as a thing that can be happy or prosperous. Happiness is the most dominant value of materialism in students in urban and rural areas. That is, students in both regions have a perception that the possession of the material as being able to make or make life prosperous.

As many as 40.3 percent of students in urban areas and 27.0 percent of rural students have a perception that life will be better if they have goods that have not been owned. Students will be happy if they can afford more goods (urban $22.6 \%$ and rural 19.1 per cent). In addition, as many as 56.5 percent of students in urban areas and 47.6 percent of rural students will be disappointed if they can not afford the desired goods. Materialistic behavior causes adverse effects. The results of Goldberg et al. (2003) suggest that more materialistic youth tend to spend more and save less. In addition, materialists are found to be difficult to save, have poor financial management, and are therefore haunted by financial anxiety (Gardarsdottir and Dittmar 2012).

\section{Behavior as Smart Consumer}

Most of the students in urban areas (80.6\%) and rural (77.8\%) are categorized as underperforming as smart consumers. The average index of behavior as a smart consumer in the less categorized students, namely 51.10 in urban and 50.49 in rural areas. Students in urban areas are more likely to seek information on goods that will be purchased via the internet (40.3\%) and families $(41.9 \%)$, while rural students are more likely to seek information from friends (46.0\%). More than half of urban students (53.2\%) and rural $(52.4 \%)$ often compare the prices of inter-store goods to obtain cheaper prices of the same quality. However, more than two-fifths of students in urban areas $(40.3 \%)$ and rural (42.9\%) never made shopping lists before shopping.

When shopping, students often buy goods on a priority scale of need or prioritize the most urgent (urban $48.4 \%$ and rural 46.0\%). As many as 43.5 percent of students in urban and 36.5 percent of students in rural areas are always researching the goods to be purchased. In addition, as many as 38.7 percent of students in urban areas and 47.6 percent of students in rural areas always read the expiration date on the packaging when choosing the purchased goods. However, only a small proportion of students always check for SNI markings on packaging of goods to be purchased (urban $6.5 \%$ and rural $11.1 \%$ ), always read the instructions or procedures for using Indonesian language (urban $6.5 \%$ and rural $23.8 \%$ ), Choose "made in Indonesia" goods rather than imported goods (urban $4.8 \%$ and rural $4.8 \%$ ). In addition, more than one third of urban (33.9) and rural 
(38.1\%) students never asked or reminded family members to request a warranty card. This does not indicate behavior as a savvy consumer when buying goods.

After making a purchase, only 16.1 percent of students in urban areas and 15.9 percent of rural students claim to always keep proof of payment after purchase. Students in urban areas $(30.6 \%)$ are more likely to keep warranty cards than rural students (22.2\%). Only 6.5 percent of students in urban areas and 9.5 percent of students in rural areas always convey an experience of dissatisfaction after purchasing goods to others. In addition, only 8.1 percent of students in urban areas and 9.5 percent of students in rural areas who always complain directly to the seller if the goods do not match what is promised. As many as one third of students in urban (33.9\%) and rural (33.3\%) will sometimes not buy again to the same seller if the seller is not satisfactory.

\section{Factors that Affecting Behavior as Smart Consumers}

The result of multiple linear regression analysis in Table 5 shows the influence of the independent variables studied (sex, region, awareness of educational materials about consumer rights and lialibilities, information sources, objective knowledge of consumer rights and lialibilities, and the value of materialism on the dimensions of success, Centrality, and happiness) to the dependent variable of behavior as a smart consumer by 15.2 percent (adjusted $\mathrm{R}^{2}$ $=0.152 ; \mathrm{p}=0.001)$. The remaining 84.8 percent is influenced by other unresearched variables such as kekosmopolitan (Simanjuntak 2014) and the intensity of consumer education access (Mubarokah 2015).

Table 5 Regression analysis results of factors that influence the behavior as smart consumers

\begin{tabular}{|c|c|c|c|}
\hline \multirow{2}{*}{ Independent Variable } & \multicolumn{2}{|c|}{ Behavior as Smart Consumer } & \multirow{2}{*}{ Sig. } \\
\hline & Unstandardize B & Standardize $\beta$ & \\
\hline Constant & 42.239 & & \\
\hline \multicolumn{4}{|l|}{ Characteristics of students } \\
\hline Gender $(1=$ male; $0=$ female $)$ & 3.426 & 0.154 & $0.089 *$ \\
\hline Region $(1=$ urban; $0=$ rural $)$ & -3.261 & -0.148 & 0.124 \\
\hline \multicolumn{4}{|c|}{$\begin{array}{l}\text { Awareness of consumer education } \\
\text { materials }\end{array}$} \\
\hline Right (index) & 0.015 & 0.022 & 0.807 \\
\hline Liabilities (index) & -0.019 & -0.044 & 0.647 \\
\hline Information source & 0.390 & 0.423 & $0.000 * * *$ \\
\hline \multicolumn{4}{|l|}{ Objective knowledge } \\
\hline Right (index) & -0.091 & -0.136 & 0.150 \\
\hline Liabilities (index) & 0.059 & 0.096 & 0.302 \\
\hline \multicolumn{4}{|l|}{ Value of Materialism } \\
\hline Success (index) & 0.047 & 0.048 & 0.638 \\
\hline Centrality (index) & -0.142 & -0.145 & 0.163 \\
\hline Happiness (index) & 0.099 & 0.116 & 0.284 \\
\hline Count F & & 3.226 & \\
\hline Adjusted $\mathrm{R}^{2}$ & & 0.152 & \\
\hline Sig & & $0.001 * * *$ & \\
\hline
\end{tabular}


The results showed that gender $(\beta=3.426 ; p=0.089)$ had a significant positive effect on behavior as a smart consumer. This shows that male students are more behave as smart consumers than female students of 3.426 points. This finding is in line with the results of Nardo et al (2011) that the average score of male consumer empowerment index is systematically better than women in all dimensions. In addition, the source of information other than the lesson $(\beta=$ $0.390 ; p=0.000$ ) has a very significant positive effect on behavior as a savvy consumer. This means an increased source of information other than the lessons will increase the behavior of smart consumers by 0.390 points.

\section{Discussion}

This study aims to analyze differences in student characteristics, awareness of educational materials about consumer rights and lialibilities, information sources, objective knowledge about consumer rights and lialibilities, materialism values, and behavior as smart consumers in junior high and junior high school students in Bogor. The results showed the number of female students more than the number of male students. Most students in urban and rural areas are in the early teen age category. This is because students are at the same level of education, the $9^{\text {th }}$ grade of junior high. Most students earn an allowance in the range of ten to twenty thousand rupiah per day. The average pocket money for students in urban areas (18 758 IDR) does not vary much with the pocket money of students in rural areas (17 412 IDR). Based on the characteristics of students, there is no significant difference between students in urban and rural areas.

The results showed that there was a significant difference between the awareness of educational materials about the rights and lialibilities of consumers to students in urban and rural areas. The average index of students enrolled in urban areas is higher than those in rural schools. This finding is in line with Mubarokah (2015), that the percentage of consumer education materials about the introduction of rights and lialibilities of consumers in rural areas is still low at 1.7 percent. In addition, there is a significant difference between objective knowledge of consumer rights in students in urban and rural areas. The average index of objective knowledge about consumer rights in students in urban areas is higher than in rural students. This shows that students in urban areas have a better understanding compared to rural students although the achievement of objective knowledge is both categorized enough.

Most students from both urban and rural areas have been informed about the characteristics of discerning consumers. The least educational consumer information obtained by students is to ensure that electronic products are equipped with an Indonesian warranty card. This is expected because students do not have the ability to buy electronic products independently, so information about the warranty card is still less socialized to students. According Simanjuntak (2014), consumer knowledge is increasing as more information is received. The sources that provide the most information about consumer education are parents, television, teachers, and the internet. Parents are the main source of students in urban and rural areas in obtaining consumer education. That is, parents are quite influential in providing consumer education to students. This finding is in line with the results of Mubarokah (2015) research that television is the main source to obtain consumer education information in urban and rural areas. Other research 
results indicate that the internet and reference groups are the primary source for obtaining information about complaints (Yuliati et al., 2016). Radio is the most informative source of information about consumer education. In line with Mubarokah (2015) which states that radio is a source of consumer education access that is rarely used by consumers in urban and rural areas.

Overall, the behavior of students as smart consumers in urban and rural terkategori less, whereas awareness of consumer education materials and objective knowledge of students in urban areas is higher than students in rural areas. This can happen because students who have awareness and good knowledge, not necessarily can apply it in everyday life. This finding is in line with Simanjuntak (2014) research results that the level of customer empowerment in regencies and cities is still low, with the condition of customer empowerment in the city better than in the district. This is allegedly due to the low level of consumer education provided to students. Consumer education in Social Science subjects is generally only inserted in the chapter "Economic Principles". Meanwhile, consumer education on Indonesian subjects is implicitly written through the text contained in the book, so that the consumer education materials provided are not delivered properly. This causes students not to understand educational materials about the rights and lialibilities of consumers given. As a result, students are unable to practice behavior as smart consumers.

The results showed that gender significantly positive effect on behavior as a smart consumer. Male students are more likely to behave as smart consumers than female students. This finding is in line with the results of Nardo et al. (2011) that the average score of male consumer empowerment index is systematically better than women in all dimensions. Sources of information have a significant positive effect on behavior as a savvy consumer. That is, increasing the number of sources of information will improve behavior as a smart consumer in junior high school students. One indicator of smart consumers is complaint behavior. The intention of the complaint is significantly influenced by the access to information that consumers get about the complaint (Yuliati et al. 2016).

The formal socialization of consumer education aims to cultivate consumer awareness and practice the skills of consumers to be assertive (Benn 2014). The results of the study found that objective students' knowledge of consumer rights was influenced by sources of information other than the lesson. That is, the more sources of information other than the lessons students receive, the better the students' objective knowledge of consumer rights. Meanwhile, objective knowledge of students about consumer liability is influenced by educational materials about consumer liability. That is, the higher the students 'awareness of educational materials about consumer liability, the better the students' knowledge of consumer liabilities. This finding is in line with McGregor (2005) which states that consumer education is able to increase consumer knowledge about rights and responsibilities. The influence of information resources on objective knowledge is stronger than consumer education materials. This shows the importance of increasing the intensity of consumer education primarily through various sources of information apart from the lessons. The results of Simanjuntak et al. (2013) shows that the intensity of following consumer education can improve consumer empowerment in both urban and rural areas. 
This study has some limitations. Firstly, there is no data on how many and which SMPs use the Education Unit Level Curriculum and Electronic School Book from Bogor City Education Office so that randomization of research sites can not be done. Therefore, the researcher determines the location of the study by region with the approval of the school. Secondly, the location of schools is located in urban areas that are representative of urban and district characteristics characterized by rural areas. However, the researcher did not record the address of the student's residence so there was a possibility that the students did not live around the school area. Thirdly, the determination of 2 Public Junior High School Dramaga as one of the selected locations in this study is less representative of rural characteristics. Fourth, data collection is done by survey technique because of the limited time given by the school so it is not possible to malakukan interview. Fifth, based on the results of content analysis in Social Science textbooks and Indonesian language, few educational materials about consumer rights and lialibilities are found. In addition, the material contained in textbooks is not explicitly explained so that many students are unaware of any educational materials about consumer rights and lialibilities. Sixth, researchers have not got a reference how to measure objective knowledge about consumer rights and lialibilities so that researchers develop their own measurement instruments. Seventh, the measurement of behavior as a smart consumer does not pass through weighting before, during, and after purchases as in consumer empowerment.

This research provides scholarly contribution for some parties, such as government especially Ministry of Trade, Ministry of Education and Culture, and other related government institution. This research can be used as input in formulating a program or curriculum that can improve behavior as a smart consumer. This research is expected to give scientific contribution to Bogor Agricultural University, which is to contribute in scientific development, especially in the field of consumer education.

\section{Conclusion}

\section{Conclusion and Suggestion}

The results of the content analysis have shown that only the consumer right number 5 is "The right to get advocacy, protection, and an endeavor to resolve the appropriate consumer protection dispute" that is not in the textbook. Educational materials on consumer rights number 2, namely "The right to choose goods and / or services and get the goods and / or services in accordance with the exchange rate and conditions and promised guarantees" most found in Social Science textbooks.

The results showed the number of female students more than the number of male students. Almost all students are in the early teen age category. In addition, most students earn an allowance in the range of ten to twenty thousand rupiah per day. The results showed that there was a significant difference between the awareness of educational materials about the rights and lialibilities of consumers in the urban and rural students with the average index score of students enrolled in urban higher than those in rural schools. Meanwhile, the sources that provide the most information about consumer education are parents, television, teachers, and the internet. Happiness is the most dominant dimension of materialism values in 
students in urban and rural areas. This indicates that students in both regions have a perception that the possession of the material as being able to make life happy or prosperous. Overall, behavior as a smart consumer in students in urban and rural areas is still low.

The result of multiple linear regression analysis showed that gender had positive significant effect on behavior as smart consumer. This shows that male students are more behaving as smart consumers than female students. In addition, the source of information other than the lesson also has a very significant positive effect on behavior as a savvy consumer. This means an increased source of information other than the lessons will improve the behavior of students as smart consumers.

\section{Suggestion}

The results showed that behavior as a smart consumer in students in urban and rural areas is still low. To improve behavior as a smart consumer to students, the efforts that can be done include: (1) Developing curriculum and module of education of cosumen which can be used in formal and non formal education. Examples of consumer education materials that may be provided are: (a) Consumer Protection Act No. 8 of 1999, particularly on consumer rights and lialibilities, (b) Introduction of consumer protection organizations and organizations; (c) Introduction to advocacy and consumer protection; ) How to file a complaint, and other material that meets the needs of today's consumers; (2) Increasing teacher awareness to always provide consumer education and its application in everyday life to be more easily understood by students; (3) Providing training to improve teachers' ability in carrying out learning containing consumer education; (4) Improving the quality of consumer education information that is easily understood with content that can educate students, especially in the effort to form a smart consumer. For example, television commercials on tips to be smart consumers; (5) Increase the source of consumer education information easily accessed by students, such as television, internet, and textbooks; (6) Increase the awareness of students to become smart consumers by inviting students to access information related to consumer education that has been available. Awareness raising can also be done by installing banners, posters, or other media whose content can motivate students to be smart consumers; and (7) The results of content analysis of consumer education materials in Social Science textbooks (IPS) and Bahasa Indonesia indicate that there is no material about consumer rights number 5 (Right to get advocacy, protection, and appropriate dispute resolution of consumer protection). Therefore, it is necessary to insert the material about consumer rights number 5, for example by mentioning the subject of consumer protection or displaying text readings with the theme "Consumer Protection".

The results of content analysis indicate that consumer education material received by students is less clear because only in the form of insertion, so it needs to be reevaluated to arrange consumer education materials more concrete so that messages can be understood by students. The results of content analysis show that there is no educational material about consumer rights and lialibilities in Social Sciences $9^{\text {th }}$ grade textbooks, so it is necessary to insert educational materials about consumer rights and lialibilities, for example in international trade chapter. 
Consumers must understand and enforce their rights so as not to be easily fooled by fraudulent producers.

\section{References}

Anwas, O.M. (2011). Membangun media massa publik dalam menanamkan pendidikan karakter. Jurnal Pendidikan dan Kebudayaan. 17(6): 680-690.

Benn, J. (2004). Consumer education between 'consumership' and citizenship: experiences from studies of young people. International Journal of Consumer Studies. 28(2): 108-116.

[BPKN] Badan Perlindungan Konsumen Nasional. (2012). Materi kurikulum perlindungan konsumen di pendidikan formal: upaya BPKN menuju konsumen muda cerdas sejak dini. [Internet].

Gardarsdottir, R.B., Dittmar, H. (2012). The relationship of materialism to debt and financial well-being: the case of Iceland's perceived prosperity. Journal of Economic Psychology. 33: 471-481.

Goldberg, M.E., Gorn, G.J., Peracchio, L.A., Bamossy, G. (2003). Understanding materialism among youth. Journal of Consumer Psychology. 13(3): 278288.

Johan, A., Cahyo, H. (2016). Perilaku konsumen materialistik: perspektif pembelian, compulsive buying, dan environmental attitudes. 6(1): 177-192.

Joung, H.M. (2013). Materialism and clothing post-purchase behaviors. Journal of Consumer Marketing. 30(6): 530-537.

[KEMENDAG] Kementerian Perdagangan Republik Indonesia. (2015. Laporan Akuntabilitas Kinerja [internet]. [Diunduh 2017 Februari 7]. Tersedia pada: www.kemendag.go.id

Knights, C. (2000). Educating tomorrow's consumers today: an introduction to consumer education. England (UK): Steve Paveley Design. ISBN: 1902391 262.

McGregor, S. (2005). Sustainable consumer empowerment through critical consumer education: a typology of consumer education approaches. Internation Journal of Consumer Studies. 29(5): 437-447.

Mubarokah, U. (2015). Pengaruh akses pendidikan konsumen dan gaya hidup terhadap keberdayaan konsumen di wilayah perkotaan dan perdesaan Bogor [skripsi]. Bogor (ID): Institut Pertanian Bogor.

Nardo, M., Loi, M., Rosati, R., Manca, A. (2011). The consumer empowerment index: a measure of skills, awareness and engagement of European consumers. JRC Scientific and Technical Reports. Luxembourg: Publication Office of the European Union. ISBN: 978-92-79-19926-4.

[PDSPK] Pusat Data dan Statistik Pendidikan dan Kebudayaan, Kementerian Pendidikan dan Kebudayaan. (2016). Statistik Persekolahan Sekolah Menengah Pertama (SMP) 2015/2016. Jakarta (ID): Setjen, Kemendikbud.

Ratnasari, A. (2008). Teknologi informasi untuk masyarakat perdesaan. Kaunia. 4(1): 19-38.

Richins, M.L., Dawson, S. (1992). A consumer value orientation for materialism and its measurement: scale development and validation. The Journal of Consumer Research. 19(3): 303-316. 
Simanjuntak, M., Amanah, S., Puspitawati, H., Asngari, P. (2013). Modelling consumer empowerment level. Economic Journal of Emerging Markets. 5(2):109-119.

Simanjuntak, M. (2014). Tingkat keberdayaan dan strategi pemberdayaan konsumen [disertasi]. Bogor (ID): Sekolah Pascasarjana, Institut Pertanian Bogor.

Simanjuntak, M., Yuliati, L.N. (2015). Pengembangan Instrumen Indeks Keberdayaan Konsumen. Bogor (ID): Institut Pertanian Bogor. ISBN: 978602-96826-4-9.

Sramova, B. (2015). Marketing and media communications targeted to childres as consumers. Social and Behavioral Sciences. 191: 1522-1527.

Wening, S. (2012). Keterkaitan pendidikan konsumen dengan pembentukan karakter bangsa. Konaspi VII. 1-8.

Wulandari, F., Wahyono, H., Haryono, A. (2016). Pengaruh perhatian orang tua, respon pada iklan, intensitas pergaulan teman sebaya, dan pemahaman siswa pada mata pelajaran ekonomi terhadap perilaku konsumsi siswa kelas VII SMPN 2 Nglegok Kabupaten Blitar tahun ajaran 2015/2016. Jurnal Pendidikan Ekonomi. 9(2): 116-123.

Yuliati, L.N., Rahmawati, Y., Suistika, R.S. (2016). Determinants affecting customer's complaint intention (a case study on the state electricity company). International Journal of Management and Applied Science. 2 (12). ISSN: 2394-7926. 